\title{
Author Correction: Proteomic profiling and genome-wide mapping of O-GlcNAc chromatin- associated proteins reveal an O-GlcNAc-regulated genotoxic stress response
}

Yubo Liu (1), Qiushi Chen (D), Nana Zhang, Keren Zhang, Tongyi Dou, Yu Cao, Yimin Liu, Kun Li, Xinya Hao, Xueqin Xie, Wenli Li, Yan Ren (1) \& Jianing Zhang (1)

Correction to: Nature Communications https://doi.org/10.1038/s41467-020-19579-y, published online 19 November 2020.

The original version of this Article incorrectly described and discussed the protein NRF1 as "nuclear factor erythroid 2-related factor-1", while the correct full name of the NRF1 protein studied in this Article is "nuclear respiratory factor 1". Any inference regarding nuclear erythroid 2-related factor-1 have been removed and do not otherwise affect the reported results. The PDF and HTML version of the Article as well as Supplementary Data 16 have been corrected to reflect this change.

Published online: 16 November 2021

\section{Additional information}

Supplementary information The online version contains supplementary material available at https://doi.org/10.1038/s41467-021-26886-5.

\footnotetext{
(c) (i) Open Access This article is licensed under a Creative Commons Attribution 4.0 International License, which permits use, sharing, adaptation, distribution and reproduction in any medium or format, as long as you give appropriate credit to the original author(s) and the source, provide a link to the Creative Commons license, and indicate if changes were made. The images or other third party material in this article are included in the article's Creative Commons license, unless indicated otherwise in a credit line to the material. If material is not included in the article's Creative Commons license and your intended use is not permitted by statutory regulation or exceeds the permitted use, you will need to obtain permission directly from the copyright holder. To view a copy of this license, visit http://creativecommons.org/licenses/by/4.0/.
}

(c) The Author(s) 2021 